\title{
Exogamy versus endogamy
}

\author{
H.-G. TITTMAR \\ University of Ulster, Newtownabbey, Northern Ireland
}

\begin{abstract}
Exogamy and endogamy are considered in terms of kinship and the selection mechanism underlying mate selection. It is argued that the contact-promoting behaviors, which are precopulatory, act as criteria for the selection of an optimum breeding partner.
\end{abstract}

It is accepted that differences in population density and distribution are determined by food supply, and that the former lead to differences in breeding systems (see Hinde, 1982). Yet whatever the breeding system adopted, it is of genetic importance to a species to have some principles by which it is determined who will mate with whom. Otherwise, close inbreeding may result, which can increase the percentage of homozygosity and, with it, the probability of the emergence of deleterious traits (Keeton, 1980). Of necessity, therefore, a process exists whose role it is to ensure that an individual will breed with a mate of the same species, and also not breed with a close relative (for its development, see Hinde, 1982). This process is characterized by endogamy and exogamy, respectively.

Exogamy, or incest avoidance, refers to mating outside close kin (i.e., not between siblings, nor between parent and offspring). In terms of kinship, the rule of exogamy promotes mating with the less familiar (Barash, 1977).

Outbreeding is, however, constrained by the rules of endogamy and homogamy. The former defines for an individual the group that contains eligible mates, whereas the latter refers to the tendency toward a natural selection made according to similarities. Homogamy encompasses the tendency for like to mate with like (Spencer, 1979).

The tardy balance between exogamy and endogamy is, perhaps, illustrative among quail (Coturnix c. japonica). Adult male quail copulate preferentially with females that resemble, yet differ from, the individuals with whom they have been reared (Bateson, 1978). Perhaps, the greater rate of mating within demes than between demes (Keeton, 1980 ), is a reflection of this fine balance between attraction to like, and the rejection of close kin?

Not only has incest avoidance amongst primates been documented, but also that closed primate groups will meet and exchange females frequently, even though the adult males are antagonistic to one another (see Reynolds, 1980). Despite chimpanzee family relations being intimate and supportive, their philopatry may, however, have to give way to dispersal (see Greenwood, 1980), since their mating strategy tends toward exogamy (Reynolds, 1980).

Correspondence may be addressed to H.-G. Tittmar, Department of Psychology, University of Ulster, Newtownabbey, BT37 0QB, Northern Ireland.
Dobson (1982) concludes that one of the predominant reasons for juvenile male dispersal is to achieve outbreeding.

If emigration, or intercommunity transfer, is a response to exogamous pressures, then a mechanism of detection of close kin must exist.

It has been argued, on behalf of cascade frog tadpoles (Rana cascade), by Blaustein and O'Hara (1982), that kin recognition is not only learned, but also innate. They found that maternal half siblings were preferred over paternal half siblings, implying a stronger influence of maternal cues in sibling recognition. Mice, too, have been found to possess an ability to recognize half sibs without any prior experience of them (Kareem \& Barnard, 1982). Blaustein and O'Hara (1982) suggest that a genetic recognition system may be the mechanism of kin recognition, where odor is the phenotypic marker. If this is true, then a genetic recognition system, in part, may also serve in recognizing one's own species. Kirchhof-Glazier (1979) cross-fostered female house mice (Mus musculus) with female deermice (Peromyscus maniculatus). Such crossfostering did not prevent the females from responding to the same-species males. It was suggested, therefore, that it was not so much that species-specific odors were an imprint, as that preference behavior, in female housemice, appeared to be genetically programmed.

Social attraction, however, is not synonymous with breeding. Dewsbury (1973) concludes that copulatory patterns are highly stereotyped within species, but quite varied across species. For reproduction to be successful, required is a minimum of coordination of male and female activity with respect to insemination (Etkin, 1967). It is possible, therefore, that "familiarity" with the intraspecies copulatory pattern represents a tentative limit upon outbreeding. Since choice of mate does have great consequences for an animal's reproductive success (Barash, 1977), it is important to be able to recognize an optimum partner prior to mating.

Again, it is possible for rats to recognize their siblings (Hepper, 1983), and for male mice to avoid cues from related females in the choice of a companion, whereas females have been rather indifferent to the degree of kinship in choosing amongst males (Hayashi \& Kimura, 1983). Both Hepper and Hayashi and Kimura posit odor as the discriminant. So it makes sense to suggest that the use of pheromones in courtship is a prerequisite, if court- 
ship is to act as an isolating mechanism. Olfactory stimuli are known to carry information about the rat's social status, group membership, sex, sexual condition, and individuality (see Hepper, 1983).

Precopulatory activity of rats in a seminatural environment has been documented by Calhoun (1962), and for the laboratory rat, among others, by Adler (1973). Olfactory behaviors, common to both conditions, are:

1. nasal-nasal contact;

2. ventro-nasal contact;

3. ano-genital-nasal contact.

An extensive listing of rodent behavior is provided by Eisenberg (1967), who subsumes the above items under "initial contact and contact promoting behavior," describing them as antecedents to sexual behaviors. In grosser terms, he distinguishes among:

1. contact-promoting acts;

2. sexual acts;

3. agonistic acts; and

4. individual behaviors.

In his review, Eisenberg (1967) shows that contactpromoting acts clearly differ across species, being governed by the social systems (e.g., solitary vs. communal) and the perceived level of social tolerance. Thus, solitary species avoid contact-promoting acts, and may be limited to nasal-nasal contact, this being restricted to estrus events only. If, however, contact-promoting acts are presumptive chemical communicatory acts, then avoidance-prone species need to supplement the nasalnasal "channel" by other means. Indeed, it is in these species that marking behavior and/or sandbathing behaviors predominate. Although both of these groups of behavior patterns are listed by Eisenberg (1967) under "general maintenance behavior," Eisenberg makes a strong case that they also serve as "contact promoting," since sunbathing may equate as marking; and there can be a significant overlap between male and female sandbathing loci (e.g., in Gerbillus nanus).

It is, therefore, the precopulatory ritual that may function to delineate the limits of exogamy. Whereas for nocturnal species contact-promoting acts via chemical communication may predominate, species whose reliance on vision is predominant may, as their contact-promoting acts, include visual markers (Eisenberg, 1967). This, of course, agrees with Bateson's (1978) postulated relationship between the sexual response to an individual and its degree of novelty relative to familiar kin.
Pheromonal contact-promoting behavior (nasal-nasal for Mus musculus) has been considered (Granleese, 1982) a critical element in epigamic selection.

Contact-promoting behaviors, be they chemical, auditory, visual, or otherwise, may therefore be viewed as functioning as an isolating mechanism, by means of which an optimal breeding partner, if available, may be selected.

\section{REFERENCES}

ADLER, N. A. (1973). The biopsychology of hormones and behavior. In D. A. Dewsbury \& D. A. Rethlingshafer (Eds.), Comparative psychology: A modern survey (pp. 301-343). New York: McGraw-Hill.

BARASH, D. P. (1977). Sociobiology and behavior. London: Heinemann.

BAtESON, P. (1978). Sexual imprinting and optimal outbreeding. Nature, 273, 659-660.

Blaustein, A. R., \& O'Hara, R. K. (1982). Kin recognition in Rana cascadae tadpoles: Maternal and paternal effects. Animal Behaviour, 30, 1151-1157.

Calhoun, J. B. (1962). The ecology and sociology of the Norway rat (Public Health Service Publication No. 1108). Washington, DC: U.S. Government Printing Office.

DewsBury, D. A. (1973). Evolution and behavior: A reprise. In D. A. Dewsbury \& D. A. Rethlingshafer (Eds.), Comparative psychology: A modern survey (pp. 549-586). New York: McGraw-Hill.

DoBson, F. S. (1982). Competition for mates and predominant juvenile male dispersal in mammals. Animal Behaviour, 30, 1183-1192.

EISENBERG, J. F. (1967). A comparative study in rodent ethology with emphasis on evolution of social behavior: I. Proceedings of the United States National Museum, 122 (No. 3597). Washington, DC: Smithsonian Institution.

ETKIN, W. (1967). Social behavior from fish to man. Chicago: University of Chicago Press.

GRANLEESE, J. (1982). Copulatory behaviour and differential reproduction of laboratory mice in a two-male, one-female competitive situation. Unpublished Bachelor of Science thesis, Ulster Polytechnic.

GreENwoOD, P. J. (1980). Mating systems, philopatry and dispersal in birds and mammals. Animal Behaviour, 28, 1140-1162.

HAYASHI, S., \& KimURA, T. (1983). Degree of kinship as a factor regulating preferences among conspecifics in mice. Animal Behaviour, 31, 81-85.

HEPPER, P. G. (1983). Sibling recognition in the rat. Animal Behaviour, 31, 1177-1191.

Hinde, R. A. (1982). Ethology. Glasgow: Fontana, Collins.

KAREEM, A. M., \& BARNARD, C. J. (1982). The importance of kinship and familiarity in social interactions between mice. Animal Behaviour, 30, 594-601.

KeEton, W. T. (1980). Biological science. London: Norton.

KIrChHOF-GlaZIER, D. A. (1979). Absence of sexual imprinting in house mice cross-fostered to deermice. Physiology \& Behavior, 23, 1073-1080.

REYNOLDS, V. (1980). The biology of human action. Oxford, England: Freeman.

SPENCER, M. (1979). Foundations of modern sociology. London: Prentice-Hall. 